\title{
Replication of herpes-like viruses in haemocytes of adult flat oysters Ostrea angasi: an ultrastructural study
}

\author{
P. M. Hine *, Tina Thorne
}

Fish Health Section, Animal Health Laboratories, Department of Agriculture, Baron-Hay Court, South Perth 6151, Western Australia

\begin{abstract}
Eosinophilic intranuclear inclusions are reported from agranular haemocytes and eosinophilic granulocytes of Ostrea angasi (Sowerby, 1871). Ultrastructurally, ovoid to hexagonal capsids $98 \pm 4 \mathrm{~nm}$ (range 90 to $105 \mathrm{~nm} ; \mathrm{n}=60$ ) in diameter formed around an ovoid, fine granular inclusion at the periphery of the nucleus. Strands and rod-like configurations of dark material near the centre of the nucleus developed into a coarse granular matrix along the edge of which capsids acquired a fibrillar, vermiform or rod-like core. Many capsids appeared to degenerate along the nuclear periphery. Those passing into the cytoplasm acquired an envelope in the perinuclear space, and cytoplasmic nucleocapsids acquired an envelope when passing into endoplasmic reticulum or cytoplasmic vesicles. The few virions observed had tails and were 135 to $140 \mathrm{~nm}$ across. Nuclear stages of replication are more similar to cytomegaloviruses (Betaherpesvirinae) than to herpes simplex viruses (Alphaherpesvirinae). Incomplete replication and the low level of virion production are attributed to sampling in late summer and winter when temperatures are sub-optimal.
\end{abstract}

KEY WORDS: Ostrea angasi - Ultrastructure Herpes-like viruses - Replication

\section{INTRODUCTION}

Infections with herpes-like viruses have been reported from ostreid oysters of the genera Ostrea (Alderman 1980, Comps \& Cochennec 1993) and Crassostrea (Farley et al. 1972. Hine et al. 1992, Nicolas et al. 1992. Le Deuff et al. 1994, 1996, Renault et al. 1994a, b). These reports usually involved larvae (Hine et al. 1992, Nicolas et al. 1992, Renault et al. 1995, Le Deuff et al. 1996) or spat (Comps \& Cochennec 1993, Renault et al. $1994 a, b, 1995$ ) held at elevated temperatures (Farley et al. 1972, Alderman 1980, Hine et al. 1992, Nicolas et al. 1992, Renault et al. 1994a, b, 1995, Le Deuff et al. 1996), and the presence of herpes-like viruses was associated with substantial mortalities (Farley et al. 1972, Alderman 1980, Hine et al. 1992, Nicolas et al. 1992, Comps \& Cochennec 1993, Renault et al. 1994a, b, 1995).

Haemocytes in the connective tissue of Australian flat oysters Ostrea angasi in Tasmania (J. Handlinger pers.

\footnotetext{
- Present address: National Institute of Water and Atmospheric Research, PO Box 14-901, Kilbirnie, Wellington, New Zealand. E-mail: m.hine@niwa.cri.nz
}

comm.) and Western Australia (this study), sometimes contain intranuclear inclusions. This paper reports on these inclusions in adult oysters sampled between late summer and winter, and shows them to contain herpeslike viruses similar to those previously described in association with mortalities among larvae and spat of other oyster species cultured at elevated temperatures.

\section{MATERIALS AND METHODS}

Broodstock oysters 2 to 3 yr old from a farm at Albany, Western Australia, that experienced low level mortalities associated with Bonamia sp. infection were randomly sampled in March ( $\mathrm{n}=76)$, May $(\mathrm{n}=24)$ and June $(\mathrm{n}=20) 1994$. The oysters were opened, and, for May and June samples, small $\left(2 \mathrm{~mm}^{3}\right)$ pieces of digestive gland were immediately excised and fixed in $2.5 \%$ glutaraldehyde buffered with $0.22 \mu \mathrm{m}$ filtered seawater (FSW). In addition, a standard section through the body, containing the digestive gland, gut, gonads, gills and kidney was fixed in Davidson's fixative or 10\% formalin in FSW. Only formalin-fixed tis- 
sues, as previously described, were prepared from the March sample. Davidson's or formalin-fixed tissue was stained with haematoxylin and eosin ( $H \& E$ ) for routine examination, and Feulgen's stain for DNA. Glutaraldehyde-fixed tissues from oysters with high levels of intranuclear inclusions, determined histologically, were washed twice with FSW, post-fixed for $1 \mathrm{~h}$ in $1 \% \mathrm{OsO}_{4}$ stained with $2 \%$ uranyl acetate for 10 min and with $5 \%$ lead citrate for 5 to $6 \mathrm{~min}$, and examined on a Philips CM10 transmission electron microscope (TEM). Two formalin-fixed oysters from the March sample were prepared for TEM by de-waxing in xylene overnight, hydrating through 2 changes of $100 \%, 90 \%$ and $70 \%$ ethanol, post-fixing $1 \mathrm{~mm}^{3}$ blocks in $1 \% \mathrm{OsO}_{4}$ buffered with $0.1 \mathrm{M}$ phosphate buffer, $\mathrm{pH} 7.2$, for 1.0 to $1.5 \mathrm{~h}$, and staining as described above.

\section{RESULTS}

\section{Histology}

The connective tissue of affected oysters was infiltrated with many agranular haemocytes, and a few eosinophilic granulocytes. Twenty-seven of 120 oysters $(23 \%)$ examined under the light microscope had intranuclear inclusions in -5 to $20 \%$ of haemocytes in connective tissue, except for 2 oysters with $-40 \%$ and $\sim 80 \%$ infection. Inclusions were observed in the nuclei of agranular haemocytes and eosinophilic granulocytes as dark eosinophilic spherical to ovoid bodies containing an orange to pink eccentric ovoid inclusion. Infected nuclei were enlarged from $3.3 \pm 0.3 \mu \mathrm{m}$ (range $3.0-4.3 \mu m_{i} n=20$ ) to $4.3 \pm 0.9 \mu \mathrm{m}$ (range 3.1-6.1 $\mu \mathrm{m}$; $n=20$ ) longest dimension, and were angular or irregular in outline with deeply basophilic marginated chromatin underlying a wavy or spikey nuclear surface (Fig. 1). One or 2 eosinophilic droplets occurred in the cytoplasm of some haemocytes. Nuclear inclusions stained positively with Feulgen's stain.

Fifty-nine oysters ( $49 \%)$, including the 1 oyster with $-80 \%$ haemocyte infection, were also infected with the haemocytic protist parasite Bonamia sp. but there was no apparent difference in the frequency with which haemocytes with and without inclusion bodies phagocytosed the parasite. Continual low level mortalities among the broodstock appeared to be related to Bonamia sp. infection, rather than the presence of intranuclear inclusions

\section{Electron microscopy}

Infected cells observed at the TEM level were mainly agranular haemocytes with a few strands of rough endoplasmic reticulum (rER), dense mitochondria, a few lipid droplets and phagosomes. However, a few fibroblasts and eosinophilic granulocytes were also infected. In some haemocytes the mitochondria were grouped into juxtanuclear bodies (Fig. 2). Infected cells were readily distinguished by their enlarged nuclei, marginated heterochromatin, and irregular surface where the nuclear membrane was in contact with areas of marginated chromatin.

There were differences in the appearance of infected nuclei between March (late summer) and June (winter) samples, and as June infections appeared to be at an earlier stage than March infections, they will be described first. In June samples, infected nuclei were enlarged and divided into 2 zones, a central electronlucent zone, and a peripheral zone comprising the marginated heterochromatin and nucleolus, and perichromatin granules 72 to $80 \mathrm{~nm}$ across (Fig. 3). Prominent in each infected nucleus was an ovoid lightly staining fine granular eccentric inclusion surrounded by denser coarse granular matter (Fig, 4). Ovoid to hexagonal capsids were seen arrayed in a single layer on the surface of the ovoid fine granular inclusion (Fig. 5), or were scattered but never numerous throughout the nucleus (Figs. 3 to 5). Strands or rods of dark material (Figs. $2 \& 6$ ) usually occurred near the centre of the nucleus, and fine fibrils were sometimes observed near the strands. Groups of small dark flecks, 21 to $25 \mathrm{~nm}$ across, within the euchromatin (Fig. 3) appeared to derive from small granular dense masses at the nuclear periphery (Figs. $3 \& 5$ ). Occasionally empty capsids were arrayed along the nuclear membrane surrounded by heterochromatin (Fig. 3). Some capsids contained pleomorphic cores, varying from rod-like to vermiform, or of fine fibrillar material that only partially filled the capsid (Figs. 7 \& 8). They were scattered throughout the nucleus, but were often seen near the group of small dark flecks and the strands of dark material near the centre of the nucleus. Enveloped nucleocapsids were occasionally seen in invaginations of the nuclear membrane (Fig. 8) and in the perinuclear space (Fig. 9), but few were seen in the cytoplasm.

In the cytoplasm, juxtanuclear irregular masses of dark material, apparently deriving from $\mathrm{rER}$, were

Figs. 1 \& 2. Ostrea angasl. Oyster with $\sim 80 \%$ infected haemocytes: June 1994. Fig. 1. H\&E section of digestive gland connective tissue showing haemocytes (arrows) with hypertrophied nuclei, intranuclear inclusions and marginated heterochromatin, and a karyorrhectic nucleus (arrowhead) $(\times 675)$. Fig. 2. Infected hyalinocyte with mitochondria in a juxtanuclear body, marginated heterochromatin, dark strands at the nuclear centre, empty capsids (arrows), and penchromatin granules (arrowheads) ( $\times 16480$ ) 


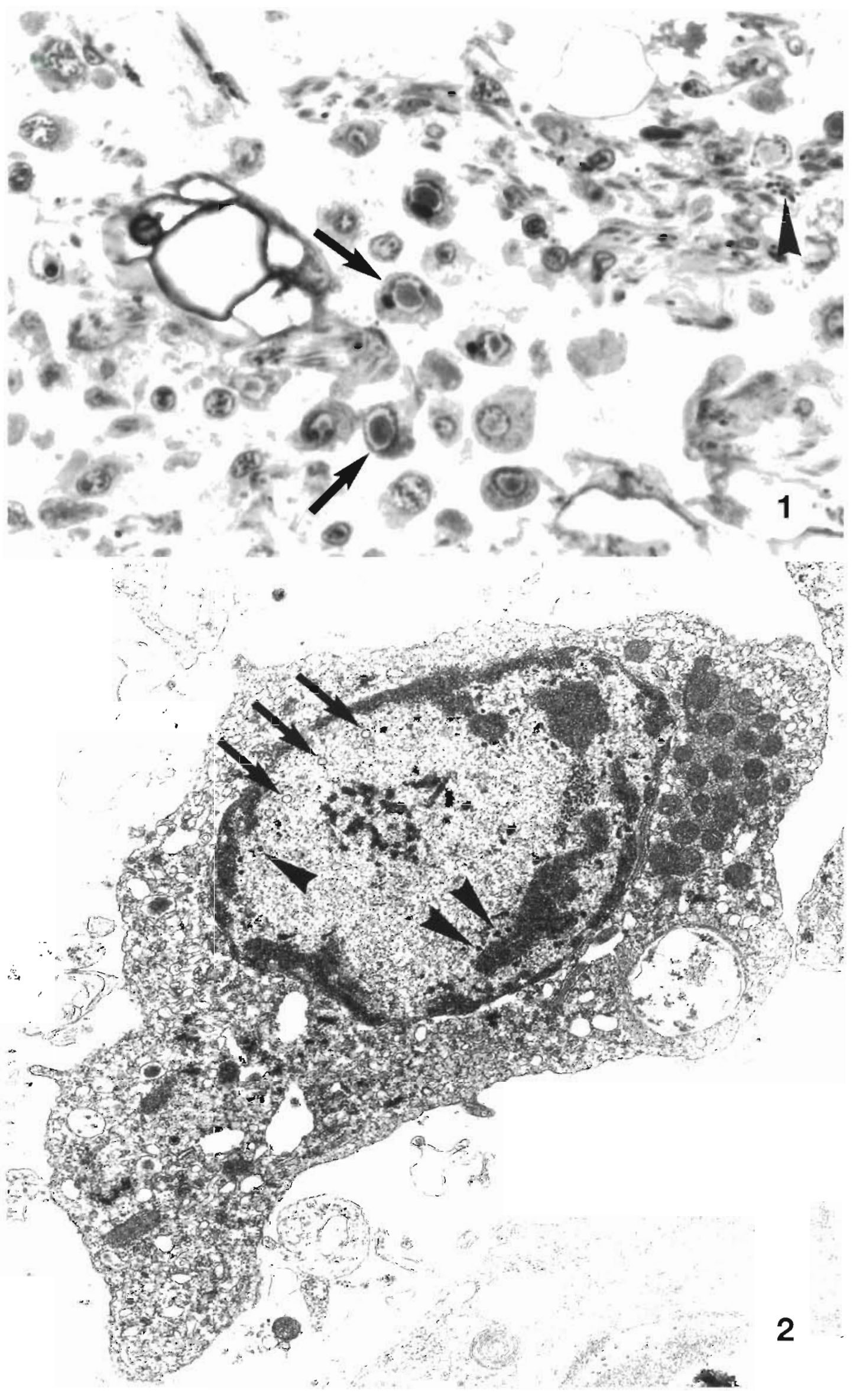




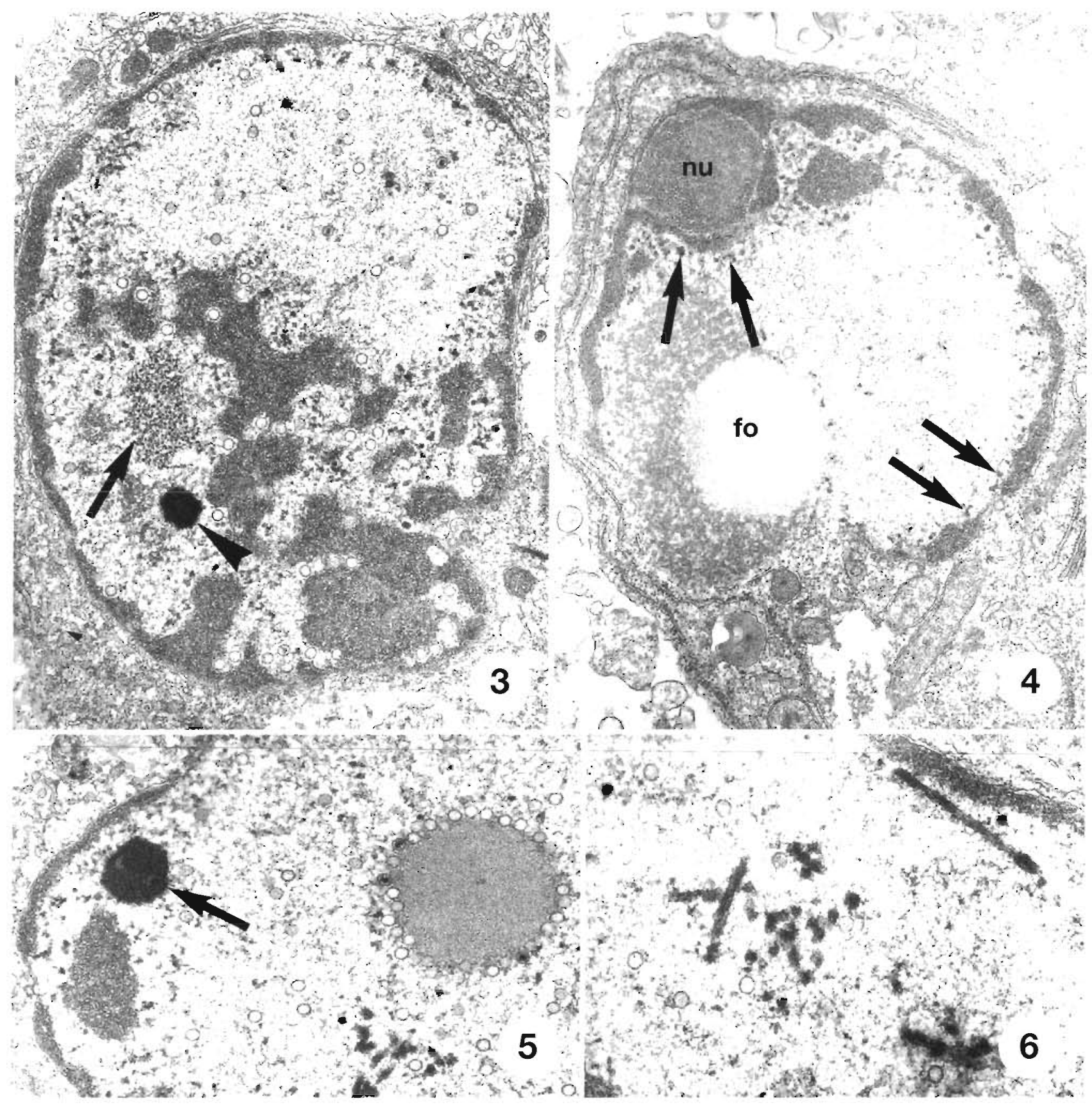

Figs 3 to 6 Ostrea angasi Intranuclear inclusions. June 1994 Fig 3 Section through the edge of an infected nucleus in which the heterochromatin appears as islets A group of small dark flecks (arrow) lies within euchromatın near a small granular dense mass (arrowhead) Note the empty capsids by the nuclear membrane and penchromatin granules ( $\times 18690$ ) Fig. 4. Fine ovoid inclusion $(f \circ)$ surrounded by a coarse granular halo Note the nucleolus (nu), marginated chromatın and perichromatan granules (arrows) $(\times 18400)$ Fig 5 Capsids along the surface of the ovoud inclusion. near strands of dense fibrillar material The small granular mass (arrow) is more electron dense than nearby heterochromatin $(\times 20220)$ Fig 6 Strands and rod-like configurations of dark material showing the fibrillar substructure $\{\times 27680$ )

often seen near Golgi cisternae in infected cells (Fig 10) Some cells contained circular profiles of confronting cisternae of $r E R$, but otherwise cytoplasmic organelles appeared normal. Unenveloped capsıds dıd not congregate in proximity to the dark granular cyto- plasmic masses, but some were seen either passing into the endoplasmic reticulum or vesicles and thus acquining an envelope (Fig 11) Enveloped capsids and nucleocapsids were never seen withın Golgl cisternae Occasionally cytoplasmic nucleocapsids were 


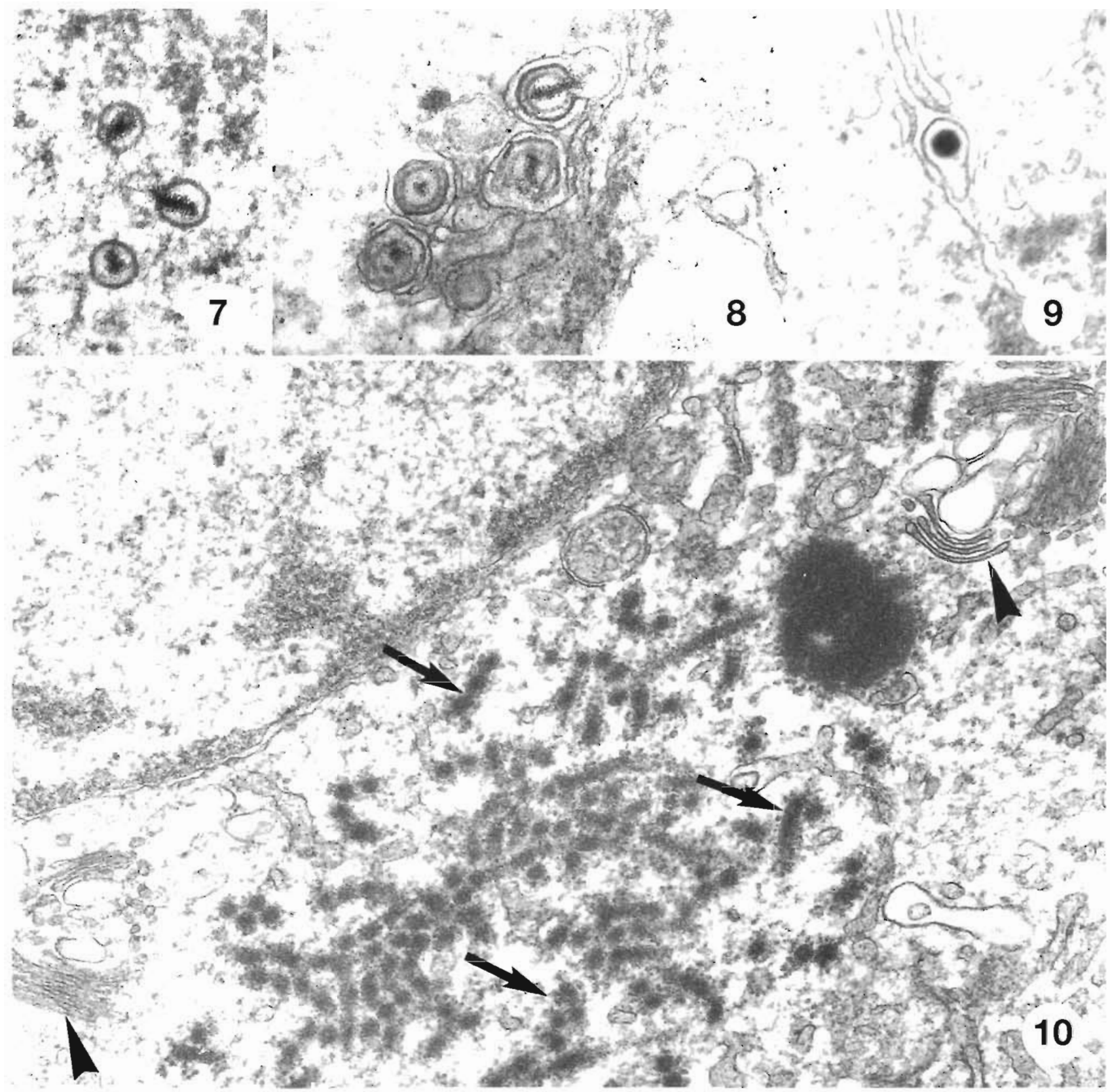

Figs. 7 to 10. Ostrea angasi. Encapsidation, envelopment and cytoplasmic changes June 1994 Fig 7 Capsids in the nucleoplasm containing a fine fibrillar core with tibrils apparently extending out of the capsid $(\times 98090)$. Fig. 8 . Enveloped capsids, some with a fibrillar core, in an invagination of the nuclear membrane $(\times 63420)$ Fig. 9. Enveloped nucleocapsid in the perınuclear space $(\times 50700)$. Fig. 10 . Cisternae of rough endoplasmic reticulum containing a dense matrix and accumulation of dense granular material (arrows), with 2 Golg1 profiles (arrowheads) ( $\times 45260$ )

grouped within concentric membranes (Fig 12). Rarely extracellular virions 135 to $140 \mathrm{~nm}$ in diameter that had a tail of $<390 \mathrm{~nm}$ overall length were observed (Fig 13).

In March samples, heterochromatin and nucleoli were marginated. A fine granular ovold inclusion with a halo of coarse granular material was still present, and the centre of nuclei contained a coarse granular matrix with spaces in the matrix giving it a retıculated appearance (Fig. 14). In some cells inter-connected strands of dark matenal occurred among the granular mass. Empty capsids and capsids containing electron-dense material, $98 \pm 4 \mathrm{~nm}$ (range 90 to $105 \mathrm{~nm} ; \mathrm{n}=60$ ) in longest diameter, occurred along the margins of the granular mass. 

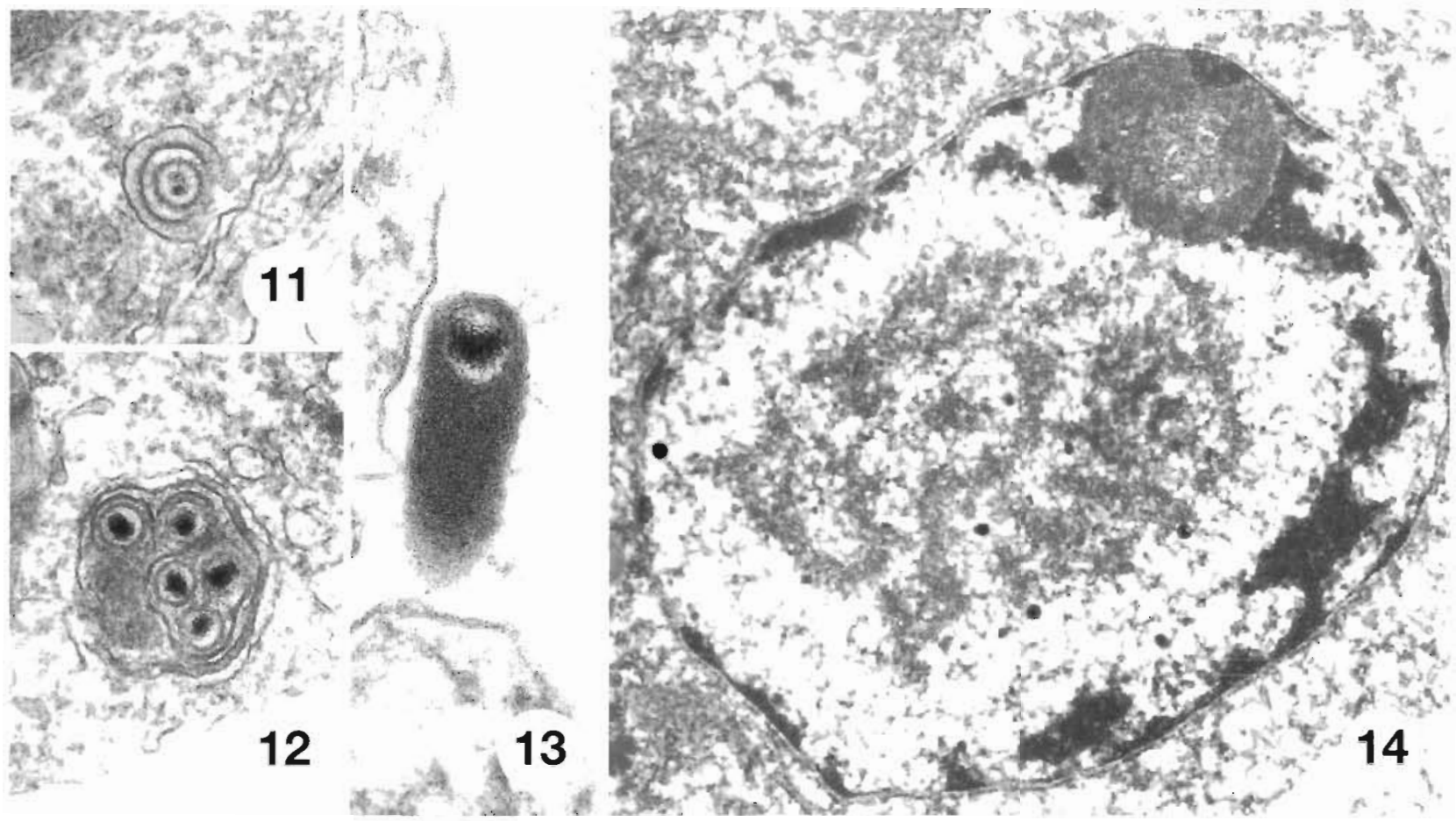

Figs. 11 to 14 Ostrea angasi Envelopment June 1994. Fig. 11. Coated capsid passing into the endoplasmic reticulum and acquiring an envelope $(\times 54170)$. Fig 12 Group of capsids within membranes in the cytoplasm $(\times 48860)$. Fig. 13. Virion with tail $(\times 93050)$ Fig. 14. March 1994. Nucleus with a granular margmated nucleolus, central reticular coarse granular matrix and nucleocapsids $(\times 19370)$

\section{DISCUSSION}

The infected haemocytes resemble the hyalinocytes of Crassostrea gigas, described by Auffret (1989), and the haemocytes of Crassostrea virginica that phagocytose the haplosporidian parasite Haplosporidium nelsonI in systemic infections (Scro \& Ford 1990). Infection of haemocytes and fibroblasts, or myocytes, is sumular to herpes-like viral infections in Ostrea edulis (Comps \& Cochennec 1993) and C. gigas (Hine et al 1992, Renault et al 1994b).

The Ostrea angasi virus resembles herpesviruses with respect to the presence of DNA, the appearance. size and genesis of capsids, the envelopment of nucleocapsids and capsids in invaginations of the nuclear membrane and the perinuclear space, and the mass of dense granular material in the cytoplasm (Rouman 1990) Similar herpes-l..ke viruses in Crassostrea gigas are labelled by antibodies raısed against channel catfish herpesvirus (LeDeuff et al. 1995) Like the herpeslike viruses of C. gigas (Hine et al. 1992, Renault et al 1994b), O angasi herpes-like viruses resemble cytomegaloviruses (CMV) (Betaherpesvinnae) in the production of dark granular masses in the cytoplasm, which are characteristic of CMV infections (Papadimitrou et al 1984, Sever et al. 1988) They differed from herpes-like viruses in C. gigas with respect to the light stanning of the fine granular intranuclear inclusion and the dense coarse granular matter surrounding it (Fig. 4), the electron-dense strands or rods with nearby fine fibrlls (Figs. 2 \& 6), and the small granular dense masses at the nuclear periphery and associated small dark flecks (Fig. 3). The coarse granular intranuclear structure seen in March samples (Fig. 14) has not been reported from $C$. gigas, while the intranuclear sacs in C. gigas (Hine et al. 1992) and intranuclear tubules in C virginuca (Farley et al. 1972) herpes-type viruses were not seen here. Tailed virions have been reported from $O$. edulis spat (Comps \& Cochennec 1993) and C. gigas larvae (Hine et al. 1992)

The stages seen here, but not in Crassostrea gigas occur during replication of mammalian herpesviruses. Small granular dense masses at the nuclear periphery have heen reported from the early stages of herpes simplex viruses (HSV) (Schwartz \& Roizman 1969) and CMV (Ruebner et al. 1965) infections, and they probably disaggregate to form the groups of small dark flecks seen later in HSV infection. (Schwartz \& Roizman 1969) Structures similar to the ovoid fine granular eccentric inclusion do not appear to have been reported in HSV and CMV infection, except for a more granular inclusion in middle to late HSV replication 
(Schwartz \& Roizman 1969; their Fig. 2D). In shape and position the ovoid inclusion resembles the host cell nucleolus, which in HSV (Sirtori \& Bosisio-Bestetti 1967, Schwartz \& Roizman 1969), and CMV infections (Ruebner et al. 1964) disaggregates into ribonucleoprotein granules, coalesced nucleolonema and amorphous matrix. However, the ovoid fine granular inclusion does not closely resemble these components, and capsids have not been reported in close association with nucleolar components.

The dark strands and rod-like configurations near the centre of nuclei resemble the early intranuclear inclusion (Cavallo et al. 1981), and the bundles of electron-dense filaments (Fong 1982), of early CMV infections. The early intranuclear inclusion appears to develop into the coarse granular matrix (Cavallo et al. 1981), seen here in March samples. The bundles of electron-dense filaments also probably develop into the coarse granular matrix, as both are the site of viral DNA production (Fong 1982, Wolber et al. 1988), in which case the early nuclear inclusion (Cavallo et al. 1981) and bundles of electron-dense filaments (Fong 1982) are probably homologous. The strands and rodlike configurations of dark material seen here are probably also homologous. The associated fibrils appear identical to the fibrillo-granular material in CMV infection of murine hepatocytes (Papadimitriou et al. 1984), which contain DNA (Fong 1982).

Nuclear inclusions in the March sample, such as the coarse granular matrix, occur later in CMV replication (Ruebner et al. 1965, Kanich \& Craighead 1972, Iwasaki et al. 1973, Smith \& de Harven 1973, Fons \& Albrecht 1986) than the inclusions seen in June samples. The coarse granular matrix has not been reported in HSV replication (Smith \& de Harven 1973). Capsids and nucleocapsids occur along the edge of the coarse matrix (Kanich \& Craighead 1972, Iwasaki et al. 1973, Smith \& de Harven 1973, Fons \& Albrecht 1986), the site of viral DNA production (Fong 1982, Wolber et al. 1988). At this site in CMV infections, fibrils of viral DNA (Fong 1982) form fibrillar, vermiform, or tadpole-shaped structures that enter the capsids (Ruebner et al. 1965, Kanich \& Craighead 1972, Fong et al. 1980, Cavallo et al. 1981), whereas in HSV infections encapsidation does not occur in association with specific inclusions (Luetzeler \& Heine 1978, Whealy et al. 1991). The strands or rods of dark material in June samples, and reticulated coarse granular inclusions in March samples, of Ostrea angasi may therefore be involved in DNA synthesis prior to encapsidation.

This study differs from previous studies on oyster herpes-like viruses as it was on adult oysters of the genus Ostrea in late summer and winter, and therefore differences in replication might be related to host age, genus, or lower temperatures. Host age and genus may not be determinative factors as the reticulated coarse granular inclusions, rod-like structures and ovoid fine granular inclusions were not reported from adult Crassostrea virginica (Farley et al. 1972), or from spat of another Ostrea sp., O. edulis (Comps \& Cochennec 1993). The association between virogenesis at high temperatures and mortalities caused by oyster herpeslike viruses is now well established (Farley et al. 1972, Hine et al. 1992, Renault et al. 1994b, 1995, Le Deuff et al. 1996) In this study, the empty intranuclear capsids, and few cytoplasmic or extracellular viral particles which suggest low levels of virogenesis, occurred in late summer and winter when temperatures are below mid-summer peaks. However, it seems unlikely that the process of replication would be different at lower temperatures, only that it may be slower or incomplete.

Variation in details of replication may also be due to different viral strains. This is true in higher vertebrates (Kanich \& Craighead 1972), where the relatively few species of CMV exist as many strains. Therefore TEM studies such as this may be used to distinguish strains within a host species of similar developmental stage. For example, the accumulation of granular endoplasmic reticulum, condensation of nuclear chromatin, paracrystalline arrangement of empty capsids and swollen mitochondria in infected Crassostrea gigas spat in France (Renault et al. 1994b, Le Deuff et al. 1996) was not observed in infected $C$. gigas larvae in New Zealand (Hine et al. 1992). It is therefore suggested that, in the absence of cell-lines for culturing these viruses and studying their molecular biology, comparative TEM studies and cross-infection experiments under variable conditions may be the best way to discriminate between these viruses.

It is recommended that before live oysters are translocated to new areas or introduced into commercial hatcheries, they should be held under crowded conditions at elevated temperatures to induce viral replication, permitting detection of inclusion bodies

Acknowledgements. We are grateful to Jonathon Bilton of Ocean Seafoods International for suppying infected oysters, Kim Elliott of the Animal Health Laboratories for preparation of material for electron microscopy, and Brett Wesney of the National Institute for Water and Atmospheric Research for preparation of the plates.

\section{LITERATURE CITED}

Alderman DJ (1980) Shellfish diseases, past, present and future. In: Proc 11th Ann Conf Shellfish Assoc Great Britain, London, p 30-40

Auffret M (1989) Comparative study of the hemocytes of two oyster species: the European flat oyster, Ostrea edulis, Linnaeus 1750 and the Pacific oyster, Crassostrea gigas (Thunberg, 1793). J Shellfish Res 8:367-373 
Cavallo T, Graves K, Cole NL. Albrecht T (1981) Cytomegalovirus: an ultrastructural study of the morphogenesis of nuclear inclusions in human cell culture. J Gen Virol 56: $97-104$

Comps M, Cochennec N (1993) A herpes-like virus from the European oyster Ostrea edulis L. J Invertebr Pathol 62:201-203

Farley CA, Banfield WG, Kasnic G, Foster WS (1972). Oyster herpes-type virus. Science 178:759-760

Fong CKY (1982) Ultrastructural localization of cytomegalovirus DNA synthesis in infected guinea-pig cells. J Gen Virol 60:235-245

Fong CKY, Bia F, Hsuing GD (1980) Ultrastructural development and persistence of guinea pig cytomegalovirus in duct cells of guinea pig submaxillary gland. Arch Viro] 64 $97-108$

Fons M, Albrecht T (1986) Cytomegalovirus: the relationship of nucleocapsid assembly to the organization of the cellulae. Arch Viral 91:351-356

Hine PM, Wesney B, Hay BE (1992) Herpesviruses associated with mortalities among hatchery-reared larval Pacific oysters Crassostrea gigas. Dis Aquat Org 12:135-142

Iwasaki Y, Furukawa T, Plotkin S, Koprowski H (1973) Ultrastructural study on the sequence of human cytomegalovirus infection in human diploid cells. Arch Ges Virusforsch 40:311-324

Kanich RE, Craighead JE (1972) Human cytomegalovirus infection of cultured fibroblasts. II. Viral replicative sequence of a wild and an adapted strain. Lab Invest 27 $273-282$

Le Deuff RM, Nicolas JL, Renault T, Cochennec N (1994) Experimental transmission of a herpes-like virus to axenic larvae of Pacific oyster, Crassostrea gigas. Bull Eur Assoc Fish Pathol 14:69-72

Le Deuff RM, Renault T, Cochennec N (1995) Antibodies specific for channel catfish virus cross-react with Pacific oyster, Crassostrea gigas, herpes-like virus. Vet Res 26: $526-529$

Le Deuff RM, Renault T, Gérard A (1996) Elfects of temperature on herpes-like virus detection among hatcheryreared larval Pacific oyster Crassostrea gigas. Dis Aquat Org 24:149-157

Luetzeler J, Heine U (1978) Nuclear accumulation of filamentous herpes simplex virus DNA late during the replicative cycle. Intervirology 10:289-299

Nicolas JL, Comps M, Cochennec N (1992) Herpes-like virus infectung Pacific oyster larvae, Crassostrea gigas. Bull Eur Assoc Fish Pathol 12 (1):11-13

Papadimitriou JM, Shellam GR, Robertson TA (1984) An ultrastructural investigation of cytomegalovirus replica-

Responsible Subject Editor: A. K. Sparks, Seittle,

Washington, USA tion in murine hepatocytes. J Gen Virol 65:1979-1990

Renault T, Cochennec N, Le Deuff RM, Chollet B (1994a) Herpes-like virus infecting Japanese oyster (Crassostred gigas) spat. Bull Eur Assoc Fish Pathol 14(2):64-66

Renault $T$, Le Deuff RM, Cochennec $N$, Chollet B, Maffart P (1995) Herpesviruses associated with high mortality levels in larvae and spat of Pacific oysters, Crassostrea gigas: a comparative study, the thermal effects on virus detection in hatchery-reared larvae, reproduction of the disease in axenic larvae. Vet Res 26:539-543

Renault T, Le Deuff RM, Cochennec N, Maffart P (1994b) Herpesviruses associated with mortalities among Pacific oyster, Crassostrea gigas, in France-comparative study. Rev Med Vet 145:735-742

Ruebner BH, Hirano T, Slusser RJ, Medearis DN (1965) Human cytomegalovirus infection. Electron microscopic and histochemical changes in cultures of human fibroblasts. Am J Pathol 46:477-494

Ruebner BH, Miyai K, Slusser RJ, Wedemeyer P, Medearis DN (1964) Mouse cytomegalovirus infection. An electron microscope study of hepatic parenchymal cells. Am J Pathol 44:799-821

Roirman B (1990) Herpesviridae: a brief introduction. In: Fields BN, Knipe DM (eds) Virology. Raven Press, New York, p 1787-1793

Schwart: J, Roizman B (1969) Similarities and differences in the di:velopment of laboratory strains and freshly isolated strains of herpes simplex virus in HEp-2 cells: electron microscopy. J Virol 4:879-889

Scro RA, Ford SE (1990) An electron microscope study of disease progression in the oyster. Crassostrea virginica, infected with the protozoan parasite, Haplosporidium nelsoni (MSX). In: Perkins FO, Cheng TC (eds) Pathology in marine science. Academic Press, New York, p 229-254

Severi B, Landini MP, Govoni E (1988) Human cytomegalovirus morphogenesis: an ultrastructural study of the late cytoplasmic phases. Arch Virol 98:51-64

Sirtori C, Bosisio-Bestetti M (1967) Nucleolar changes in KB tumour cells infected with herpes simplex virus. Cancer Res 27:367-376

Smith JD, de Harven E (1973) Herpes simplex virus and human. cytomegalovirus replication in WI-38 cells. I. Sequence of viral replication. J Virol 12:919-930

Whealy ME, Card JP, Meade RP, Robbins AK, Enquist LW (1991) Effect of Brefeldin A on alphaherpesviruses membrane protein glycosylation and virus egress. J Virol 65: 1066-1081

Wolber RA, Beals TF, Lloyd RV, Hunein FM (1988) Ultrastructural localization of viral nucleic acid by in situ hybridization. Lab Invest 59:144-151

Manuscript first received: October 19, 1996

Rewsed version accepted: March 11, 1997 